OPEN ACCESS

Edited by:

Tuck Seng Wong,

The University of Sheffield,

United Kingdom

Reviewed by:

Antonio Valle,

University of Cádiz, Spain

Li Zhou,

Jiangnan University, China

${ }^{*}$ Correspondence:

Teresa de Diego Puente

tdp@um.es

${ }^{\dagger}$ These authors have contributed equally to this work

Specialty section:

This article was submitted to Microbial Physiology and Metabolism,

a section of the journal

Frontiers in Microbiology

Received: 17 March 2021

Accepted: 18 May 2021

Published: 21 June 2021

Citation:

Lozano Terol G, Gallego-Jara J,

Sola Martínez RA, Martínez Vivancos A, Cánovas Díaz M and de Diego Puente T (2021) Impact

of the Expression System on Recombinant Protein Production

in Escherichia coli BL21.

Front. Microbiol. 12:682001. doi: 10.3389/fmicb.2021.682001

\section{Impact of the Expression System on Recombinant Protein Production in Escherichia coli BL21}

\author{
Gema Lozano Terol't, Julia Gallego-Jara', Rosa Alba Sola Martínez, \\ Adrián Martínez Vivancos, Manuel Cánovas Díaz and Teresa de Diego Puente*
}

Department of Biochemistry and Molecular Biology and Immunology (B), Faculty of Chemistry, University of Murcia, Campus of Espinardo, Regional Campus of International Excellence "Campus Mare Nostrum", Murcia, Spain

Recombinant protein production for medical, academic, or industrial applications is essential for our current life. Recombinant proteins are obtained mainly through microbial fermentation, with Escherichia coli being the host most used. In spite of that, some problems are associated with the production of recombinant proteins in E. coli, such as the formation of inclusion bodies, the metabolic burden, or the inefficient translocation/transport system of expressed proteins. Optimizing transcription of heterologous genes is essential to avoid these drawbacks and develop competitive biotechnological processes. Here, expression of YFP reporter protein is evaluated under the control of four promoters of different strength $\left(P_{T 7 l a c}, P_{t r c}, P_{t a c}\right.$, and $\left.P_{B A D}\right)$ and two different replication origins (high copy number $\mathrm{pMB} 1^{\prime}$ and low copy number p15A). In addition, the study has been carried out with the E. coli BL21 wt and the ackA mutant strain growing in a rich medium with glucose or glycerol as carbon sources. Results showed that metabolic burden associated with transcription and translation of foreign genes involves a decrease in recombinant protein expression. It is necessary to find a balance between plasmid copy number and promoter strength to maximize soluble recombinant protein expression. The results obtained represent an important advance on the most suitable expression system to improve both the quantity and quality of recombinant proteins in bioproduction engineering.

Keywords: Escherichia coli, recombinant protein, expression system, promoter, origin of replication, microbial factory

\section{INTRODUCTION}

Expression of heterologous and autologous genes is a routine method employed in several biotechnological fields such as metabolic engineering, in vivo biocatalysis, or in recombinant proteins or other high-value metabolite production (Sanchez-Garcia et al., 2016; Badenhorst and Bornscheuer, 2018; McCarty and Ledesma-Amaro, 2019). Thus, the strategy followed in a biotechnological process usually includes the expression of enzymes or complete biosynthetic pathways necessary to achieve the compound of interest (Assenberg et al., 2013; Gallego Jara et al., 2015). E. coli has traditionally been, and still is, the most used host microorganism in biotechnology. E. coli has several advantages to be employed to express heterologous proteins such as fast growth, variety of culture broths, or high number of biology tools designed to obtain genetical modifications 
(Huang et al., 2012; Blount, 2015; Vargas-Maya and Franco, 2017; Chandran Sathesh-Prabu and Lee, 2018; Xu et al., 2020).

The expression of recombinant proteins is influenced by both physical and transcriptional conditions, such as temperature, shaking, promoter strength, or number of copies of the expression vector used (Aristidou et al., 1999; Balzer et al., 2013; Niu et al., 2014; Bernal et al., 2016; Lozano Terol et al., 2019; $\mathrm{Wu}$ et al., 2019). In spite of the advantages, some problems are also associated with the production of recombinant proteins in E. coli: the formation of inclusion bodies, the inefficient protein translocation, or the metabolic burden (Mairhofer et al., 2013; Baig et al., 2014; Marschall et al., 2017). Some current strategies developed to solve these drawbacks are focused on supplementation of essential precursors or use of co-cultures (Gurramkonda et al., 2018; Slouka et al., 2019; Chiang et al., 2020; Kumar et al., 2020; Wang et al., 2020). Metabolic burden relates to imbalance suffered by a host cell when a heterologous gene is expressed. The metabolic burden is associated with energetic and precursor constraints due to the transcription and translation of non-essential proteins for the host cell. This limitation is reflected in the alteration of physiological parameters, such as growth rate, and in the downregulation of several essential metabolic pathways for the cell (Mairhofer et al., 2013; Tan et al., 2020; $\mathrm{Li}$ and Rinas, 2021). In order to minimize metabolic imbalance, several commercially available plasmids have been engineered to design each biotechnological process, choosing between different promoters and origins of replication, both responsible for the expression level of the gene/s of interest (Zaslaver et al., 2006; De Mey et al., 2007; Wang et al., 2009; Rosano and Ceccarelli, 2014; Yang et al., 2016; Jervis et al., 2019; Rosano et al., 2019).

One of the main factors affecting metabolic burden is promoter strength. lac-derived promoters $\left(\mathrm{P}_{\text {T7lac }}, \mathrm{P}_{\text {trc }}\right.$, and $\left.\mathrm{P}_{\mathrm{tac}}\right)$ are all based on the negative regulation by LacI, and the expression is induced by lactose or non-metabolizable isopropyl $\beta$-D-1-thiogalactopyranoside (IPTG), used as analogous molecule of lactose, while $\mathrm{pBAD}$ plasmids carry a BAD promoter $\left(\mathrm{P}_{\mathrm{BAD}}\right)$ positively induced by L-arabinose (Müller-Hill et al., 1968; Silverstone et al., 1970; Terpe, 2006; Brautaset et al., 2009). $\mathrm{P}_{\text {trc }}$ and $\mathrm{P}_{\text {tac }}$ promoters are considered as strong promoters and are well characterized. Genes regulated by $\mathrm{P}_{T 7}$ promoter are transcripted by the bacteriophage $\mathrm{t} 7 \mathrm{RNA}$ polymerase present in some E. coli strains, such as BL21 (DE3) (Phue et al., 2008). This polymerase is five times faster than E. coli RNA polymerase, so $\mathrm{P}_{\text {T7 lac }}$ is considered a very strong promoter (William Studier et al., 1990; Mertens et al., 1995). Although the induction system is different from lac, the $\mathrm{P}_{\mathrm{BAD}}$ promoter is considered a medium-strong promoter, with a lower force of expression than $\mathrm{P}_{\text {tac }}, \mathrm{P}_{\text {trc }}$, and $\mathrm{P}_{\text {T7 lac }}$ (Guzman et al., 1995).

Replication origin (ori) of the replicon is the main component influencing the copy number of an expression vector and therefore in cell metabolic burden (Smolke and Keasling, 2002; Wang et al., 2009). There are many different origins including prokaryotic, eukaryotic, viral, and others unidentified (Wang et al., 2009). Specifically for enterobacteria, there are large differences in the number of copies related to the different origins (Jahn et al., 2016). For example, pMB1 (also known as pBR322) is related to medium copy number plasmids (15-20 copies/cell), some pMB1 derivatives have high copy number plasmids (500-700 copies/cell), while p15A is related to low PCNs (10 copies/cell) (Lin-Chao et al., 1992).

In this study, expression of the Kringle recombinant yellow fluorescent protein (KrYFP) has been evaluated in E. coli BL21 (DE3) using different expression systems. Thus, $\mathrm{P}_{\text {T7 lac }}, \mathrm{P}_{\text {trc }}, \mathrm{P}_{\text {tac }}$, and $\mathrm{P}_{\mathrm{BAD}}$ were selected as promoters to control YFP expression. Differences between these promoters have been studied in many works, although in most of them, the expression study has been carried out in different vector backbones (Lee and Keasling, 2005; Choi et al., 2010; Wu et al., 2010; Balzer et al., 2013). In the present work, selected promoters were cloned into a pet backbone with two different replication origins (high and low copy number). Induction was studied with two different carbon sources: glucose and glycerol. Moreover, protein expression system was tested in an E. coli BL21 $\triangle a c k A$ strain, which shows higher recombinant protein production with respect to the BL21 wild-type strain due to the low acetate produced and excreted to the extracellular medium (Kim and Cha, 2003; Kim et al., 2015; Lozano Terol et al., 2019). Hence, we also expect to observe an increase in YFP expression.

Together, the results try to shed light on the process of expression vector and strain selection to optimize a recombinant protein production process, essential to achieve a successful yield. Moreover, results contributes to increase the metabolic burden knowledge to obtain synthetic biology models that allow predicting the behavior of the host cell and develop robust biofactory cells (Wu et al., 2016; Mühlmann et al., 2018).

\section{MATERIALS AND METHODS}

\section{Expression Vector Constructions}

All primers and strains used in this study are listed in Table 1, and plasmids constructed and employed as templates are listed in Table 2. To construct expression vectors, the pSF-pA-PromMCSKrYFP (pSF-pMB1'-YFP) plasmid was employed as a template. In order to replace the $\mathrm{pMB1}$-derived ori (denoted as $\mathrm{pMB1}^{\prime}$ in this study), the pSF-pMB1'-YFP vector was amplified, except the original $\mathrm{pMB1}^{\prime}$ region, by using the pair of primers PSFYFP SwaI Fwd and pSFYFP PacI Rev. The p15A ori was amplified from the pZ8-pTac plasmid employing p15A PacI Fwd and p15A SwaI Rev primers. Both amplification products were digested with $\mathrm{PacI}$ and SwaI restriction enzymes and ligated to obtain the plasmid pSF-p15A-YFP with the replication origin p15A. Construction of vectors were carried out with these two backbones, pSFpMB1'-YFP and pSF-p15A-YFP, by inserting the promoter with regulator section in the multicloning site region of the plasmid. The $\mathrm{P}_{T 7}$ promoter region and lac regulatory operator $\left(\operatorname{lacI}^{q}\right.$ promoter, lacO, and lacI gene) were amplified from pet28a-MBP employing PT7 SalI Fwd and PT7 HindIII Rev primers, amplified region and vectors were digested with SalI and HindIII restriction enzymes, and ligated to obtain pSF-pMB1'-T7-YFP and pSFp15A-T7-YFP vectors. Sequence coding $\mathrm{P}_{\text {trc }}$ promoter and lac regulatory operator was amplified from pTrcECT using PTrc SalI Fwd and PTrc EcoRI Rev; both plasmids and PCR product were digested with SalI and EcoRI restriction enzymes and were 
TABLE 1 | Primers and strains used in this study.

\begin{tabular}{|c|c|c|}
\hline Primer & \multicolumn{2}{|l|}{ Sequence $5^{\prime} \rightarrow 3^{\prime}$} \\
\hline PT7 Sall Fwd & \multicolumn{2}{|c|}{ GGTGGTGTCGACTCACTGCCCGCTITCCAGT } \\
\hline PT7 HindIII Rev & \multicolumn{2}{|c|}{ GGTGGTAAGCTTAGAGGGGAATTGTTATCCGC } \\
\hline PTrc Sall Fwd & \multicolumn{2}{|c|}{ GTTGTTGTCGACGACACCATCGAATGGTGCAA } \\
\hline PTrc EcoRI Rev & \multicolumn{2}{|c|}{ GTTGTTGAATTCTTGTTATCCGCTCACAATTCC } \\
\hline PTac SallFwd & \multicolumn{2}{|c|}{ GTTGTTGTCGACGACACCATCGAATGGTGCAA } \\
\hline PTac Hindlll Rev & \multicolumn{2}{|c|}{ GTTGTTAAGCTTCCGGGAATTCTGTTTCCTGT } \\
\hline PBAD Spel Fwd & \multicolumn{2}{|c|}{ GTTGTTACTAGTTTATGACAACTTGACGGCTAC } \\
\hline PBAD EcoRI Rev & \multicolumn{2}{|c|}{ GTTGTTGAATTCAAAAAAACGGGTATGGAGAAACAG } \\
\hline p15A Pacl Fwd & \multicolumn{2}{|c|}{ GGTGGTTTAATTAAGGAAGATGCCAGGAAGATACT } \\
\hline p15A Swal Rev & \multicolumn{2}{|c|}{ GGTGGTATTTAAATIITCGTTCCACTGAGCGTCA } \\
\hline pSFYFP Swal Fwd & \multicolumn{2}{|c|}{ GGTGGTATTTAAATITCCGAACTCTCCAAGGCC } \\
\hline pSFYFP Pacl Rev & \multicolumn{2}{|c|}{ GGTGGTTTAATTAAGTTCGATAGCCCAAGGTAACCAA } \\
\hline Strain & Description & Source \\
\hline Top10F' & 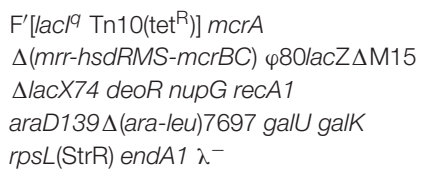 & Invitrogen \\
\hline BL21 (DE3) & $\begin{array}{l}\mathrm{F}^{-} \text {ompT gal dcm lon hsdSB }\left(r B^{-} m B^{-}\right) \\
\lambda(\mathrm{DE} 3)\end{array}$ & Promega \\
\hline BL21 (DE3) $\triangle a c k A$ & $\begin{array}{l}\mathrm{F}^{-} \text {ompT gal dcm lon hsdSB }\left(r B^{-} m B^{-}\right) \\
\lambda(\mathrm{DE} 3) \text { ackA:Kan }\end{array}$ & $\begin{array}{l}\text { Lozano Terol } \\
\text { et al., } 2019\end{array}$ \\
\hline
\end{tabular}

Restriction nuclease sites are resalted and are in bold.

ligated to generate pSF-pMB1' - trc-YFP and pSF-p15A-trc-YFP vectors. Construction of pSF-pMB1'-tac-YFP and pSF-p15A-tacYFP was carried out by $\mathrm{P}_{\text {tac }}$ promoter and regulatory lac operator from pZ8-pTac PCR using PTac SalI Fwd and PTac HindIII Rev primers. Amplified sequence and backbone vectors were digested with SalI and HindIII restriction enzymes and ligated to generate complete plasmids. The $\mathrm{P}_{\mathrm{BAD}}$ promoter and araC regulatory gene were amplified from $\mathrm{pBAD} 24$ vector employing PBAD SpeI Fwd and PBAD EcoRI Rev. The PCR product was digested and inserted in both digested plasmids through SpeI and EcoRI restriction enzyme sites to generate $\mathrm{pSF}-\mathrm{pMB1} 1^{\prime}$-BAD-YFP and pSF-p15A-BAD-YFP plasmids.

\section{Growth and Expression Analysis}

Escherichia coli BL21 (DE3) wild type or ackA-deficient strains were made competent by the rubidium chloride method (Hanahan, 1983). Chemically competent cells were transformed by heat shock at $42^{\circ} \mathrm{C}$ with the constructed pSF-pMB1'-YFP or pSF-p15A-YFP vectors. Transformed cells were grown in a Synergy H1 Hybrid Multi-Mode Reader to simultaneously measure growth at $600 \mathrm{~nm}$ (optical density $\mathrm{OD}_{600}$ ) and fluorescence, at $520 \mathrm{~nm}$ excitation and $542 \mathrm{~nm}$ emission. Then, 96-well sterilized plates were filled with $200 \mu \mathrm{l}$ of complex TB7 medium with glucose $(20 \mathrm{mM})$ or glycerol $(40 \mathrm{mM})$ as carbon sources. To prevent evaporation and permit aeration, 96-well multiplates were covered with an adhesive gas-permeable sheet (Sigma Aldrich). Cultures were inoculated with precultures to an initial $\mathrm{OD}_{600}$ of $0.05 \mathrm{U}$ and induced at $0.5 \mathrm{U}$ with $0-2 \mathrm{mM}$ IPTG or L-arabinose. TB7 composition was $10 \mathrm{~g} / \mathrm{L}$ tryptone
TABLE 2 | Plasmids used and constructed in this study.

\begin{tabular}{|c|c|c|}
\hline Plasmid & Description & Source \\
\hline pet28a-MBP & $\begin{array}{l}\text { pMB1 ori, lacl } \mathrm{P}_{T 7} \text { promoter, } \mathrm{Kan}^{\mathrm{R}} \text {, } \\
\text { Maltose Binding Protein (MBP) Phusion } \\
\text { tag }\end{array}$ & Lab deposit \\
\hline pTrcECT & $\begin{array}{l}\text { pMB1 ori, lacl, } P_{\text {trc }} \text { promoter, } \mathrm{Amp}^{\mathrm{R}} \text {. } \\
\text { ectABC (Ectoine biosynthetic operon } \\
\text { from Halomonas elongate) expression }\end{array}$ & $\begin{array}{l}\text { pTrcECT was a gift } \\
\text { from Xixian Xie } \\
\text { Ning et al., } 2016\end{array}$ \\
\hline pZ8-pTac & p15a ori, lacl, $P_{\text {tac }}$ promoter, $\operatorname{Kan}^{R}$ & $\begin{array}{l}\text { pZ8-Ptac was a gift } \\
\text { from Timothy Lu } \\
\text { Cleto et al., } 2016\end{array}$ \\
\hline pBAD24 & $\begin{array}{l}\text { pMB1 ori, L-arabinose } P_{B A D} \text { promoter, } \\
\text { Amp }^{R} \text {. }\end{array}$ & Lab deposit \\
\hline $\begin{array}{l}\text { pSF-pA- } \\
\text { PromMCS- } \\
\text { KrYFP } \\
\text { (pSF-pMB1'- } \\
\text { YFP) }\end{array}$ & 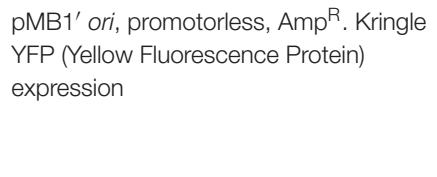 & Oxgene \\
\hline pSF-p15A-YFP & $\begin{array}{l}\text { p15A ori, promotorless, Amp }{ }^{R} \text {. Kringle } \\
\text { YFP (Yellow Fluorescence Protein) } \\
\text { expression }\end{array}$ & This study \\
\hline $\begin{array}{l}\text { pSF-pMB1'-t7- } \\
\text { YFP }\end{array}$ & $\begin{array}{l}{\text { pMB1' ori, lacl } P_{T 7} \text { promoter, Amp }}^{R} \text {. } \\
\text { Kringle YFP (Yellow Fluorescence } \\
\text { Protein) expression }\end{array}$ & This study \\
\hline $\begin{array}{l}\text { pSF-pMB1'- } \\
\text { trc-YFP }\end{array}$ & 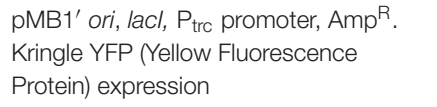 & This study \\
\hline $\begin{array}{l}\text { pSF-pMB1'- } \\
\text { tac-YFP }\end{array}$ & 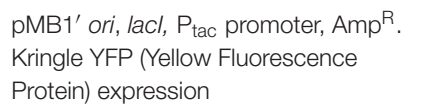 & This study \\
\hline $\begin{array}{l}\text { pSF-pMB1'- } \\
\text { BAD-YFP }\end{array}$ & $\begin{array}{l}\mathrm{pMB1}^{\prime} \text { ori, L-arabinose } \mathrm{P}_{\mathrm{BAD}} \text { promoter, } \\
\mathrm{Amp}^{\mathrm{R}} \text {. Kringle YFP (Yellow } \\
\text { Fluorescence Protein) expression }\end{array}$ & This study \\
\hline $\begin{array}{l}\text { pSF-p15A-T7- } \\
\text { YFP }\end{array}$ & $\begin{array}{l}\text { p15A ori, lacl } \mathrm{P}_{T 7} \text { promoter, } \mathrm{Amp}^{\mathrm{R}} \text {. } \\
\text { Kringle YFP (Yellow Fluorescence } \\
\text { Protein) expression }\end{array}$ & This study \\
\hline $\begin{array}{l}\text { pSF-p15A-trc- } \\
\text { YFP }\end{array}$ & $\begin{array}{l}\text { p15A ori, lacl, } P_{\text {trc }} \text { promoter, Amp }{ }^{R} \text {. } \\
\text { Kringle YFP (Yellow Fluorescence } \\
\text { Protein) expression }\end{array}$ & This study \\
\hline $\begin{array}{l}\text { pSF-p15A-tac- } \\
\text { YFP }\end{array}$ & $\begin{array}{l}\text { p15A ori, lacl, } P_{\text {tac }} \text { promoter, Amp }{ }^{R} \text {. } \\
\text { Kringle YFP (Yellow Fluorescence } \\
\text { Protein) expression }\end{array}$ & This study \\
\hline $\begin{array}{l}\text { pSF-p15A- } \\
\text { BAD-YFP }\end{array}$ & $\begin{array}{l}\text { p15A ori, L-arabinose } P_{B A D} \text { promoter, } \\
\text { Amp }^{R} \text {. Kringle YFP (Yellow } \\
\text { Fluorescence Protein) expression }\end{array}$ & This study \\
\hline
\end{tabular}

buffered at pH 7.0 with $100 \mathrm{mM} \mathrm{K}_{2} \mathrm{HPO}_{4}$. Cultures were grown in triplicate with double orbital shaking at $37^{\circ} \mathrm{C}$ for $48 \mathrm{~h}$. The specific growth rate was determined as previously described (Lozano Terol et al., 2019).

\section{YFP Concentration Determination}

In order to quantify YFP produced, cultures at stationary growth step were harvested at $4,000 \times g$ for $15 \mathrm{~min}$ at $4^{\circ} \mathrm{C}$. Cells were disrupted by sonication for $2 \mathrm{~min}$ (40 s each pulse) using a Vibra Cell sonicator (Sonicator Sonics \& Materials, Newton, United Kingdom). Lysates were analyzed by electrophoresis SDS-PAGE with 10\% acrylamide gels using Mini-PROTEAN Tetra Cell (Biorad, California, CA, United States) followed by Coomassie staining (Fisher Scientific, Madrid, Spain). Standard 


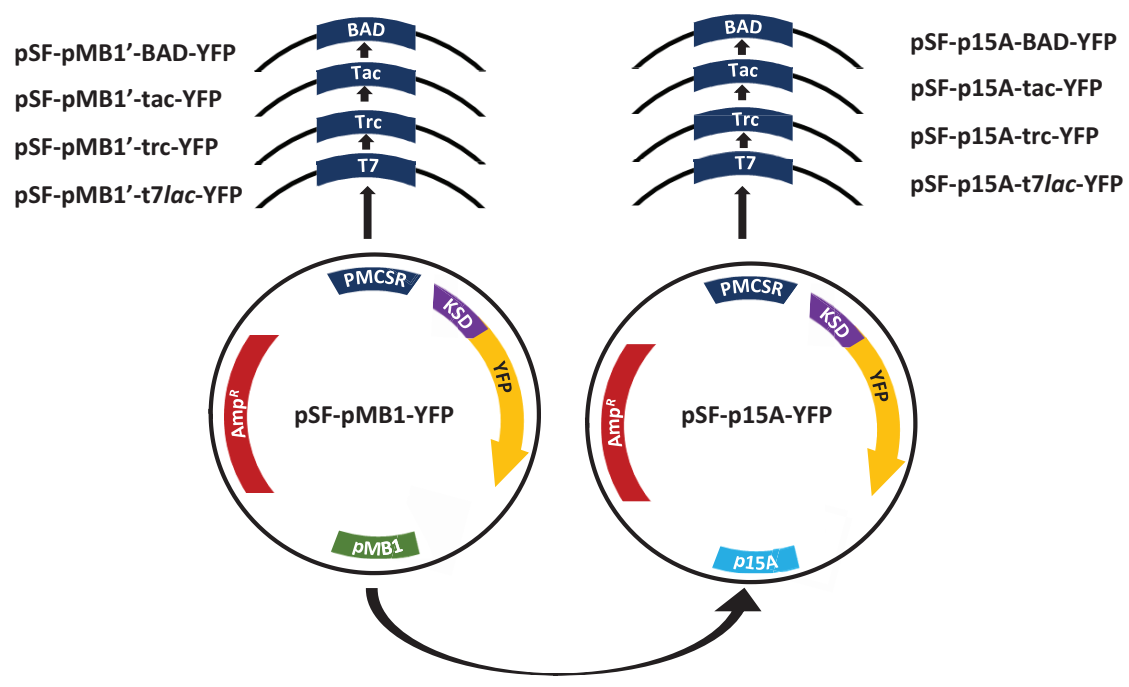

FIGURE 1 | Scheme of expression vectors constructed in this study. PMCSR, promoter multicloning site region; KSD, Kozak Shine-Dalgarno; YFP, yellow fluorescent protein; $\mathrm{Amp}^{\mathrm{R}}$, ampicillin resistance.

curve was constructed to calculate YFP concentration by densitometric analysis using ImageJ Gel Analyzer software (Rueden et al., 2017).

\section{Recombinant Protein Solubility Study}

To evaluate the solubility of the overexpressed YFP protein, chemically competent cells harboring constructed pSF-pMB1' YFP or pSF-p15A-YFP vectors were grown overnight in batch mode at $37^{\circ} \mathrm{C}$ with orbital shaking $(250 \mathrm{rpm})$. Culture medium and inductor concentration were selected in expression analysis. Pellets were harvested by centrifugation $(20 \mathrm{~min} ; 4,500 \times g)$ and resuspended in native buffer $\left(50 \mathrm{mM} \mathrm{K}_{2} \mathrm{HPO}_{4}, 500 \mathrm{mM}\right.$ $\mathrm{NaCl}, \mathrm{pH}$ 8). Cells were disrupted by sonication for $2 \mathrm{~min}(40 \mathrm{~s}$ each pulse) using a Vibra Cell sonicator (Sonicator Sonics \& Materials, Newton, United Kingdom). The lysates were clarified by centrifugation at $14,000 \times g$ for $30 \mathrm{~min}$ at $4^{\circ} \mathrm{C}$ to obtain supernatants (soluble protein extracts). Pellets were resuspended again with denatured buffer $\left(50 \mathrm{mM} \mathrm{K}_{2} \mathrm{HPO}_{4}, 500 \mathrm{mM} \mathrm{NaCl}\right.$, urea $6 \mathrm{M}, \mathrm{pH}$ 8) and incubated under shaking for $30 \mathrm{~min}$. Finally, cells were centrifugated at $14,000 \times g$ for $30 \mathrm{~min}$ at $4^{\circ} \mathrm{C}$ to isolate supernatants (insoluble protein extracts). To analyze YFP solubility, electrophoresis SDS-PAGE with 10\% acrylamide gels was carried out. Protein gels were run under denaturing conditions using Mini-PROTEAN Tetra Cell (Biorad, California, CA, United States) followed by Coomassie staining (Fisher Scientific, Madrid, Spain). ImageJ Gel Analyzer software was used for densitometric quantification (Rueden et al., 2017).

\section{RESULTS AND DISCUSSION}

\section{Construction of Two Different Replication Sets of Expression Vectors}

To evaluate the influence of replication origin on expression of recombinant proteins in E. coli BL21, p15A ( $\sim 10$ copies/cell) and a high copy number derived from pMB1 ori (500-700 copies/cell), denoted as pMB1', were selected (Selzer et al., 1983; Lin-Chao et al., 1992). To avoid influence by other vector components in expression, a common backbone was chosen for all constructions with the same ribosomal binding site sequence (Shine Delgarno sequence), the vector pSF-pMB1'YFP (pMB1' origin) (Table 1). The pSF-p15A-YFP was built from this, which was exactly the same as the previous one, except for the origin (p15A). One of the most important aspects to consider when designing a recombinant protein production process is the choice of the promoter system. Together with the replication system, it will be decisive for the level of expressed recombinant protein. We selected the prokaryotic $\mathrm{P}_{\text {T7lac }}, \mathrm{P}_{\text {trc }}$, $\mathrm{P}_{\mathrm{tac}}$, and $\mathrm{P}_{\mathrm{BAD}}$ promoters. The first three are based on the negative regulation by $\mathrm{LacI}^{\mathrm{Q}}$ and the last induced by L-arabinose. A scheme of the plasmids constructed for this study is shown in Figure 1. The resulting plasmids were named pSF-pMB1' -T7lacYFP (6,131 bp), pSF-pMB1' -trc-YFP (6,059 bp), pSF-pMB1'-tacYFP (5,969 bp), pSF-pMB1'-BAD-YFP (5,815 BP), pSF-p15AT7lac-YFP (5,749 bp), pSF-p15A-trc-YFP (5,677 bp), pSF-P15Atac-YFP (5,587 bp), and pSF-p15A-BAD-YFP (5,433 bp).

\section{Yellow Fluorescent Protein Expression Under Different Induction Conditions}

To know the behavior of an expression system under different inductor concentrations is essential to optimize a protein expression process. Here, to study how the constructed plasmids expressed the recombinant YFP, different induction conditions were evaluated. Thus, IPTG and L-arabinose 0 (control), 0.01, $0.05,0.1,0.5,1$, and $2 \mathrm{mM}$ were tested, and maximal expressions observed for each vector were normalized to 100\% (Figure 2). As shown in Figure 2, all lac-based systems showed the highest YFP expression from $0.1 \mathrm{mM}$ IPTG, while for the $\mathrm{P}_{\mathrm{BAD}}$ promoter, it was necessary to have a $2 \mathrm{mM}$ L-arabinose concentration. 
Moreover, induction profiles were similar in glucose and glycerol cultures and for wt or ackA-deficient mutant of E. coli. Thus, $0.1 \mathrm{mM}$ was selected as the optimal IPTG concentration for lacbased vectors and $2 \mathrm{mM}$ for vectors with $\mathrm{P}_{\mathrm{BAD}}$. The difference in optimal concentration of inducers is probably a consequence of all-or-none expression. The $\mathrm{P}_{\mathrm{BAD}}$ and lac promoters give rise to a gene expression known as all-or-none when induced with natural lactose or L-arabinose, respectively. This phenomenon refers to the fact that, at sub-saturated concentrations of inducer, a homogeneous level of induction is not obtained, but rather cultures in which there is a percentage of cells totally induced and another that is not induced. The gratuitous inducer IPTG is a non-metabolizable lactose analog that can freely cross the cell wall and membrane. In this sense, using IPTG as inducer, homogeneous cultures are achieved at different concentrations, which allows us to optimize the expression in a tighter way, and to use lower concentrations of inducer (Khlebnikov and Keasling, 2002). However, at the moment, no analog to Larabinose is known that allows to eliminate this phenomenon (Afroz et al., 2014).

As shown in Figure 2, in most conditions assayed, a basal expression without inducer was observed at long culture times (see also control expression in Figure 3A). This basal expression was negligible in $\mathrm{P}_{\mathrm{BAD}}$ promoter-based vector because AraC represses translation and $\mathrm{L}$-arabinose is absolutely needed for induction (Schleif, 2010). The highest basal expression was observed for $\mathrm{P}_{\text {trc }}$ and $\mathrm{P}_{\text {tac }}$ promoter vectors. lac promoters are known to have leaky transcription, that is, transcription occurs when the inducer is absent (Rosano and Ceccarelli, 2014). This fact was observed in cultures transformed with $\mathrm{P}_{\operatorname{trc}}$ and $\mathrm{P}_{\text {tac }}$ p15A vectors, in spite of carrying the LacQ improved version (Penumetcha et al., 2010). However, $\mathrm{P}_{\text {T7lac }}$ showed a low basal expression, in spite of being a lac promoter, probably due to double repression (both, $\mathrm{P}_{\text {T7lac }}$ promoter and phage T7 RNA polymerase). Basal expression observed in $\mathrm{P}_{\text {trc }}$ and $\mathrm{P}_{\text {tac }}$ promoter vectors could be a drawback when a toxic protein for cell is overexpressed.

\section{Inducer Concentration Influence on Yellow Fluorescent Protein Expression Time}

In order to deepen the influence of inducer concentration on YFP production, expression rates were calculated for all the cultures (data not shown), but these rates were not affected by inductor concentration. However, the inducer concentration was fundamentally reflected in the decrease in the time of YFP expression. Thus, in all cases, as the inducer concentration increased, the expression of the recombinant protein was observed earlier. In Figure 3A, the YFP expression of E. coli wt carrying the pSF-pMB1'-tac-YFP and growing with glucose as carbon source at different IPTG concentrations is shown. Basal expression was observed in control culture (IPTG $0 \mathrm{mM}$ ) at long culture times. However, when IPTG was present, expression was observed earlier, although from IPTG, $0.1 \mathrm{mM}$ differences in the time of expression were almost negligible. The same expression profile was observed for all cultures carrying lac

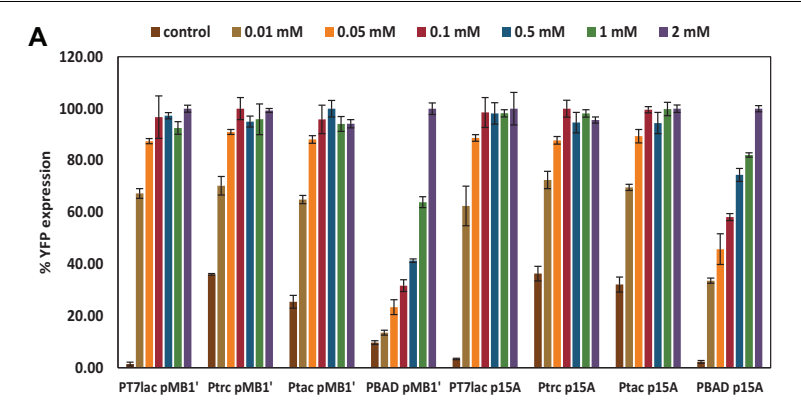

B
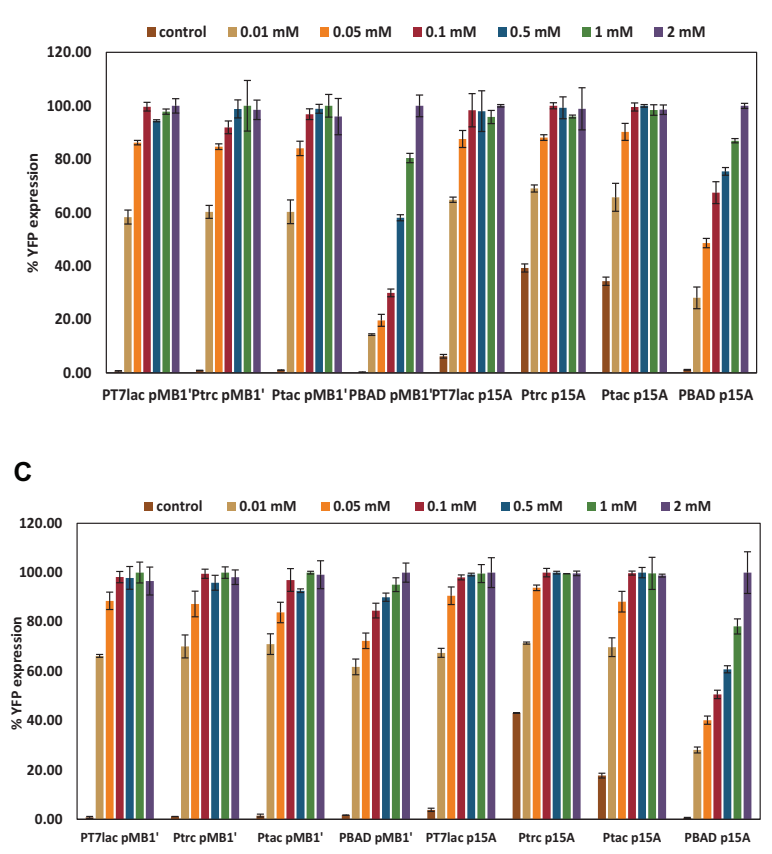

D

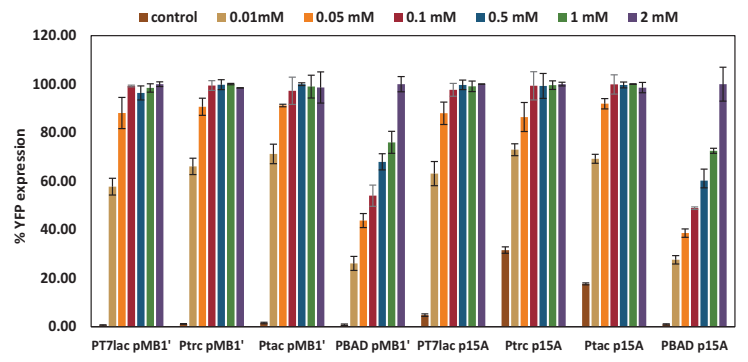

FIGURE 2 | Percentage of yellow fluorescent protein (YFP) expression with respect to maximal expression for each plasmid under different inductor conditions. The YFP expressions selected were the highest achieved at stationary growth phase. (A) E. coli wt growing with glucose as carbon source. (B) E. coli wt growing with glycerol as carbon source. (C) E. coli $\triangle a c k A$ growing with glucose as carbon source. (D) E. coli $\triangle$ ackA growing with glycerol as carbon source.

vectors. In Figure 3B, expression time (in hours after the inducer addition) is shown with respect to the concentration of inducer added for E. coli wt transformed with the six constructed lac 
A

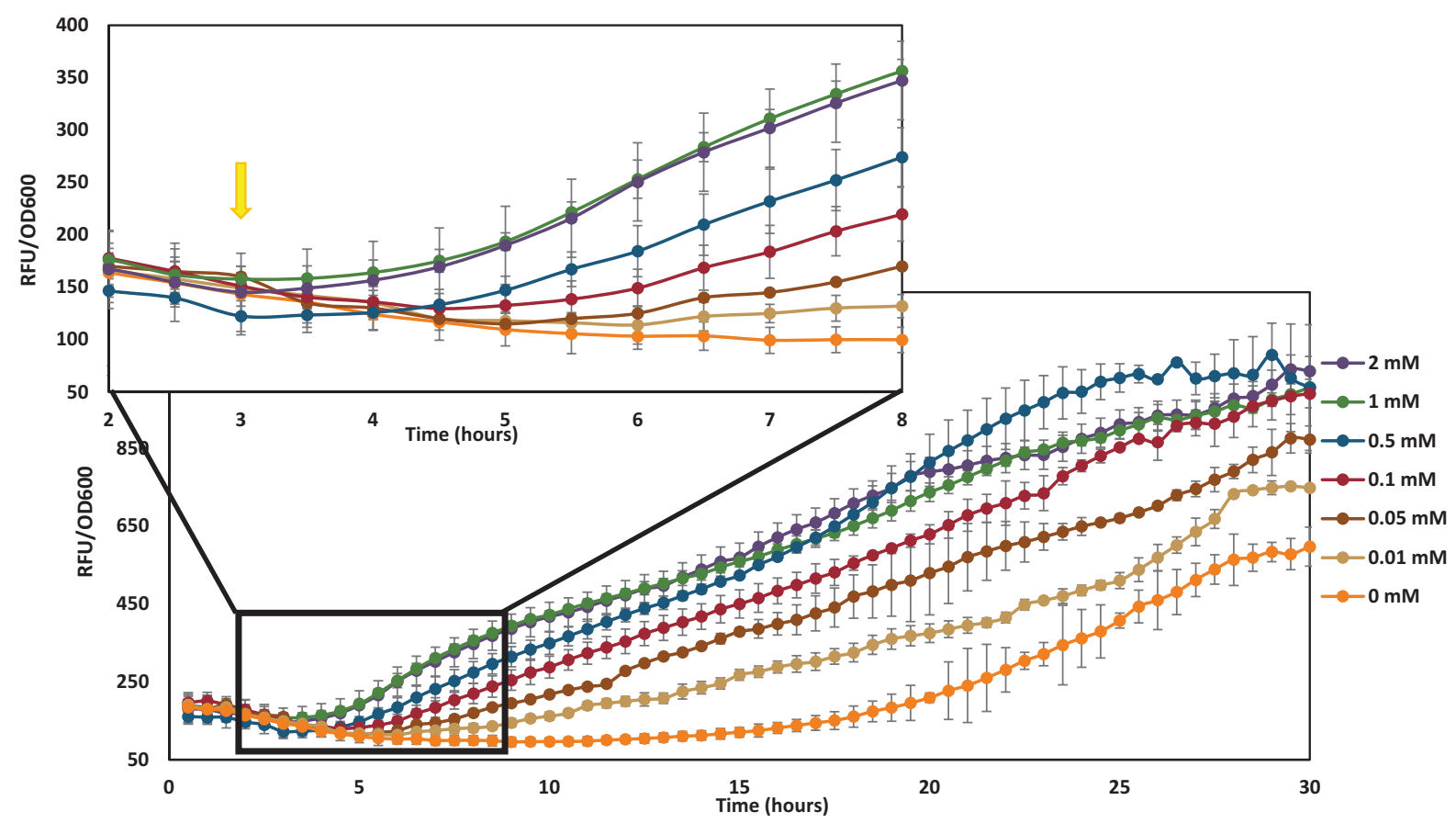

B

C
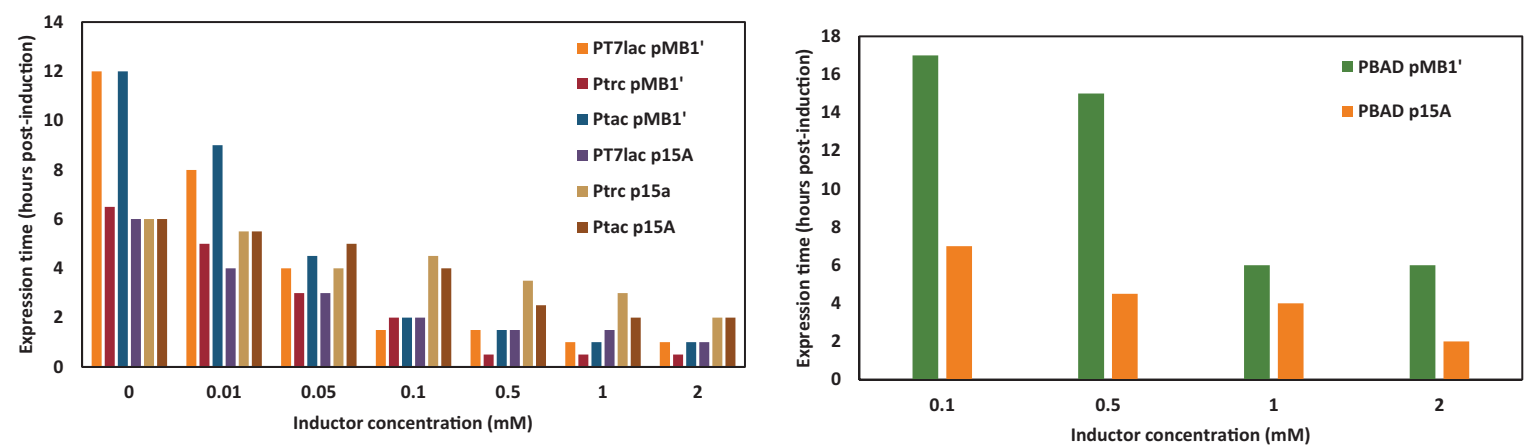

D

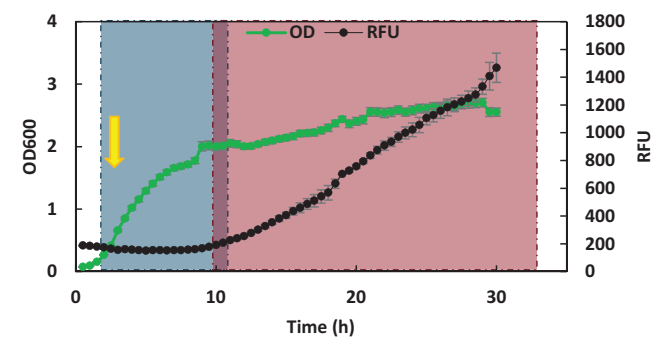

E

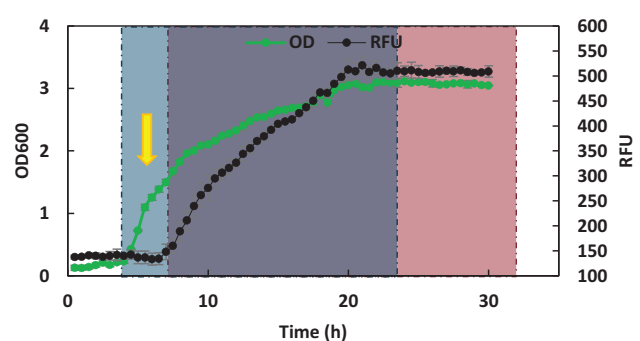

FIGURE 3 | Dependence of inductor on YFP expression time. (A) YFP expression of $E$. coli wt carrying the pSF-pMB1'-tac-YFP and growing with glucose as carbon source at different IPTG concentrations. Yellow arrow shows induction time with $0.1 \mathrm{mM} \mathrm{IPTG.} \mathrm{(B)} \mathrm{YFP} \mathrm{expression} \mathrm{time} \mathrm{(in} \mathrm{hours} \mathrm{after} 0.1 \mathrm{mM} \mathrm{IPTG}$ addition) of E. coli wt carrying the different lac plasmids constructed growing in TB7 supplemented with glucose as carbon source at different IPTG concentrations. (C) YFP expression time (in hours after $2 \mathrm{mM} L$-arabinose addition) of $E$. coli wt carrying the $\mathrm{P}_{\mathrm{BAD}}$ plasmids constructed growing in TB7 supplemented with glucose as carbon source at different L-arabinose concentrations. (D) E. coli wt carrying pSF-pMB1'-BAD-YFP growing with glucose as carbon source. (E) E. coli wt carrying pSF-pMB1'-BAD-YFP growing with glycerol as carbon source. Green dots show grown at $600 \mathrm{~nm}$, while black dots show YFP fluorescence in arbitrary units (RFU). Gray square corresponds with culture growth, and pink square indicates YFP expression. Purple square indicates hours when culture is growing and expressing YFP simultaneously. Yellow arrow shows $2 \mathrm{mM}$ L-arabinose induction time. 


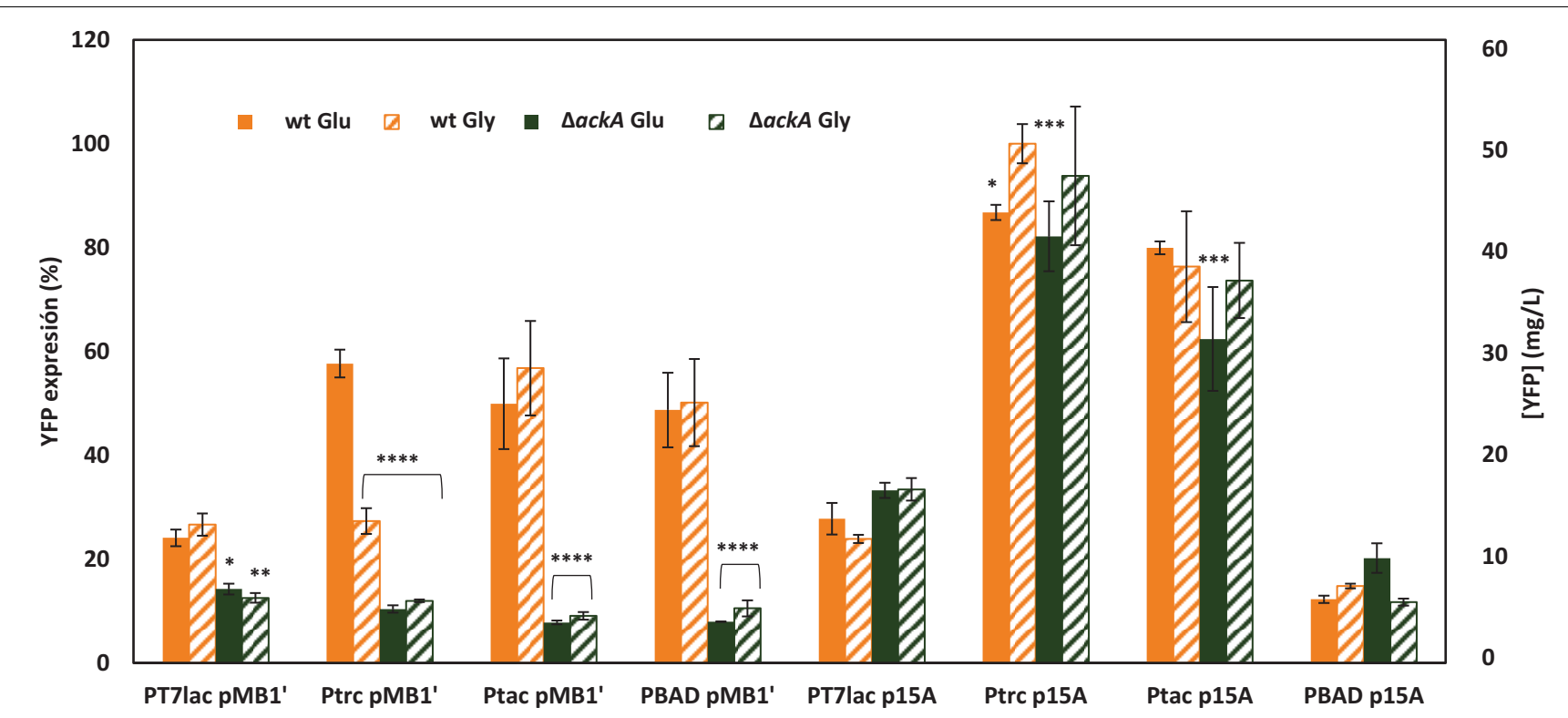

FIGURE 4 | YFP expression of E. coli wt or deficient ackA mutant growing with glucose or glycerol as carbon sources carrying different expression system vectors. Expression is shown as a percentage with respect to expression of E. coli wt transformed with the plasmid pSF-p15A-trc-YFP growing with glycerol as the $100 \%$. Secondary y-axis shows YFP concentration (mg/L). Expression of $E$. coli wt is shown in orange and E. coli $\Delta a c k A$ in green. Glucose cultures are in solid bars, while glycerol supplemented cultures are shown in striped bars.

vectors growing in TB7 supplemented with glucose. As can be seen, in the absence of inductor, basal expression started at 6-17 h post-induction, due to insufficient LacI expression. However, at $0.1 \mathrm{mM}$ IPTG, YFP expression was observed at 1$4 \mathrm{~h}$ after induction. Cultures carrying $\mathrm{P}_{\mathrm{BAD}}$ vectors did not show expression until L-arabinose was at $0.1 \mathrm{mM}$, due to the all-ornone phenomenon (Figure 3C). Moreover, expression times were much longer in $\mathrm{P}_{\mathrm{BAD}}$ than in lac vectors when glucose was the sole carbon source due to catabolite repression (Figures 3D,E). Hence, $\mathrm{P}_{\mathrm{BAD}}$ promoter is regulated by this phenomenon, in addition to L-arabinose induction. Due to the non-PTS nature of glycerol, catabolite repression is not observed when cultures are supplemented with glycerol as carbon source (Figure 3E).

\section{Effects of the Different Expression Systems and Conditions on the Yellow Fluorescent Protein Expression}

In order to compare the expression of the recombinant protein YFP under the selected induction conditions $(0.1 \mathrm{mM}$ IPTG and $2 \mathrm{mM}$ L-arabinose) with the different constructed vectors, triplicates of each combination were carried out in the same multiwell plate. In this way, it was possible to compare the expression of YFP in E. coli wt and $\triangle a c k A$ mutant growing with glucose or glycerol and transformed with each plasmid. Figure 4 shows the expression observed at stationary growth phase in each culture. The expression is shown in percentage with respect to the maximum expression reached (E. coli wt growing with glycerol as carbon source transformed with the plasmid pSF-p15A-trc-YFP). Moreover, YFP expressed was quantified, and the concentration (mg of protein/L of culture) is also shown. Statistical testing involving two-way ANOVA was carried out with Graphpad Prism 7.0 in order to evaluate statistically significant differences between maximal expression condition observed in each plasmid with respect to the other conditions $[p$-value $<0.0001(* * * *)$, $<0.001\left(^{* * *}\right),<0.01\left(^{* *}\right)$, and $\left.<0.05\left(^{*}\right)\right]$.

Results showed that the highest expression was achieved with the vectors with the lowest number of copies, which contained the p15A origin. High copy number vectors have been previously associated to a lower protein production than medium and low copy plasmids (Jones et al., 2000; Silva et al., 2012). On the contrary, $\mathrm{P}_{\mathrm{BAD}}$ showed higher YFP expression with high copy plasmid, probably due to the weaker strength of $\mathrm{BAD}$ promoter with respect to lac. Thus, the combination of a high copy number origin of replication and a strong promoter caused a metabolic mismatch, which triggered a decrease in YFP production. This metabolic burden has been, and continues to be, widely studied, since it implies a loss of productivity (Wu et al., 2016). Thus, not only the production of recombinant proteins but also the presence of the plasmid in the host cell has several metabolic and physiological consequences such as alterations in growth rate or differential expression of essential metabolic enzymes (Silva et al., 2012).

In order to increase the knowledge between YFP expression and metabolic burden, growth rates were calculated for those cultures with the highest YFP expression observed for each promoter. Moreover, growth rate of wt and ackA mutant without any plasmid and containing the expression vector without any promoter were also calculated. Growth curves of empty strains and containing promoterless vectors are shown in Figure S1, and growth rates are shown in Table 3. Empty 
wt and ackA-deficient strains showed the highest rates. Strains containing vector without any promoter showed a great decrease in growth rate, revealing a metabolic mismatch due to replication and maintenance of the additional plasmid DNA in the cell. Comparing strains containing $\mathrm{pMB1}^{\prime}$ with $\mathrm{p} 15 \mathrm{~A}$ vectors, high copy number plasmids caused a greater decrease in growth rate. Knowledge about why this metabolic imbalance occurs is still insufficient, certain studies point to a collapse in the cellular translation machinery in the face of an excess of extrinsic mRNA from the heterologous gene/genes, which is in concordance with growth rates observed in this study (Mairhofer et al., 2013; Tan et al., 2020). Moreover, decrease in growth rate also showed a dependence on strength promoter although lower than replication origin. This result highlights that metabolic burden is mainly due to transcription and, to a lesser extent, to recombinant protein translation, which has been recently discussed (Li and Rinas, 2020).

Glycerol has become a potential alternative to glucose, the traditional carbon source, due to its lower cost as a subproduct of biodiesel production (Clomburg and Gonzalez, 2013). Results observed in this study show a similar expression for cultures growing with glucose or glycerol as carbon source, so glycerol could be a better alternative without a decrease in the final yield. Regarding the ackA-deficient mutant, expression with high copy vectors was much lower than that observed for the wt strain. However, when low copy plasmids were employed, $\Delta a c k A$ showed a similar expression to wt. The low expression measured with $\mathrm{pMB1}^{\prime}$ was probably due to an increase in the metabolic burden caused by ackA gene depletion, which agrees with the growth rates. Thus, ackA-deficient mutant showed approximately half of wt growth rate. Previous studies have observed an increase in recombinant protein expression when E. coli BL21 ackA knockout strain was used as host. Thus, ackA depletion avoids acetate overflow and energy waste associated to it. However, none of these studies used a plasmid with such a high copy number as pMB1' (Kim and Cha, 2003; Kim et al., 2015; Lozano Terol et al., 2019). To our knowledge, this is the first expression study carried out in E. coli BL21 $\triangle$ ackA with a high copy number plasmid and a strong promoter.

To compare all conditions, statistical testing involving twoway ANOVA of the maximal YFP expression achieved with each vector was carried out (Figure 5). Figure 5 shows significant differences of maximal expression compared with YFP expression with pSF-p15A-trc-YFP, the highest observed. Quantitative analysis revealed a YFP maximal concentration of $53.09 \mathrm{mg} / \mathrm{L}$, which agrees with other studies focused on GFP production in E. coli (Chew and Tan, 2012; Fragoso-Jiménez et al., 2019). All expressions, except the ones corresponding to pSF-p15A-tac-YFP were significantly lower. Thus, for low copy vectors, $\mathrm{P}_{\text {trc }}$ promoter achieved threefold higher expression than $\mathrm{P}_{\text {T7lac }}$ and 5.5-fold than the $\mathrm{P}_{\mathrm{BAD}}$. It is interesting to highlight how the joint influence of the promoter strength and the number of copies associated with each of the two replication origins used is observed. Thus, for $\mathrm{P}_{\text {T7lac }}$, the strongest promoter of the four studied, the expression of YFP is lower than for $\mathrm{P}_{\text {trc }}$ and $\mathrm{P}_{\text {tac }}$, both in the low and high copy number vector. This low expression might be due to the metabolic stress caused by excess transcripts or to an insufficient expression of RNA T7 polymerase (Vethanayagan and Flower, 2005; Mairhofer et al., 2013). These results indicate the need to find an adequate balance between these two factors, which will need to be optimized for each production process.

TABLE 3 | Growth rates calculated for empty strains and containing promoterless vectors growing with glucose or glycerol as carbon sources.

\begin{tabular}{|c|c|c|c|c|}
\hline & E. coli strain & $\begin{array}{l}\text { Carbon } \\
\text { source }\end{array}$ & $\begin{array}{l}\text { Expression } \\
\text { vector }\end{array}$ & Growth rate \\
\hline wt Glu & BL21 & Glucose & $\begin{array}{l}\text { No vector } \\
\text { (empty strain) }\end{array}$ & $0.99 \pm 0.04$ \\
\hline wt Gly & BL21 & Glycerol & $\begin{array}{l}\text { No vector } \\
\text { (empty strain) }\end{array}$ & $0.72 \pm 0.03$ \\
\hline $\begin{array}{l}\text { wt Glu } \\
\text { pMB1' }\end{array}$ & $\mathrm{BL} 21$ & Glucose & $\begin{array}{l}\text { No } \\
\text { promoter-YFP } \\
\text { pMB1' }\end{array}$ & $0.54 \pm 0.05$ \\
\hline $\begin{array}{l}\text { wt Gly } \\
\text { pMB1' }\end{array}$ & BL21 & Glycerol & $\begin{array}{l}\text { No } \\
\text { promoter-YFP } \\
\text { pMB1' }\end{array}$ & $0.43 \pm 0.03$ \\
\hline $\begin{array}{l}\text { wt Glu } \\
\text { p15A }\end{array}$ & BL21 & Glucose & $\begin{array}{l}\text { No } \\
\text { promoter-YFP } \\
\text { p15A }\end{array}$ & $0.63 \pm 0.03$ \\
\hline $\begin{array}{l}\text { wt Gly } \\
\text { p15A }\end{array}$ & BL21 & Glycerol & $\begin{array}{l}\text { No } \\
\text { promoter-YFP } \\
\text { p15A }\end{array}$ & $0.53 \pm 0.1$ \\
\hline$\Delta$ ackA Glu & BL21 $\triangle a c k A$ & Glucose & $\begin{array}{l}\text { No vector } \\
\text { (empty strain) }\end{array}$ & $0.56 \pm 0.05$ \\
\hline$\Delta$ ackA Gly & BL21 $\triangle a c k A$ & Glycerol & $\begin{array}{l}\text { No vector } \\
\text { (empty strain) }\end{array}$ & $0.50 \pm 0.07$ \\
\hline $\begin{array}{l}\triangle \text { ackA Glu } \\
\text { pMB1' }\end{array}$ & BL21 $\triangle a c k A$ & Glucose & $\begin{array}{l}\text { No } \\
\text { promoter-YFP } \\
\text { pMB1' }\end{array}$ & $0.19 \pm 0.02$ \\
\hline $\begin{array}{l}\triangle \text { ackA Gly } \\
\text { pMB1' }^{\prime}\end{array}$ & BL21 $\triangle a c k A$ & Glycerol & $\begin{array}{l}\text { No } \\
\text { promoter-YFP } \\
\text { pMB1' }\end{array}$ & $0.18 \pm 0.02$ \\
\hline $\begin{array}{l}\Delta \text { ackA Glu } \\
\text { p15A }\end{array}$ & BL21 $\triangle a c k A$ & Glucose & $\begin{array}{l}\text { No } \\
\text { promoter-YFP } \\
\text { p15A }\end{array}$ & $0.42 \pm 0.03$ \\
\hline $\begin{array}{l}\Delta \text { ackA Gly } \\
\text { p15A }\end{array}$ & $\mathrm{BL} 21 \Delta a c k A$ & Glycerol & $\begin{array}{l}\text { No } \\
\text { promoter-YFP } \\
\text { p15A }\end{array}$ & $0.30 \pm 0.03$ \\
\hline $\begin{array}{l}\text { PT7lac } \\
\text { pMB1' }\end{array}$ & BL21 & Glucose & $\begin{array}{l}\text { P }_{\text {T7lac }} \text {-YFP } \\
\text { pMB1' }^{\prime}\end{array}$ & $0.31 \pm 0.03$ \\
\hline$P_{\text {trc }} \mathrm{pMB1}^{\prime}$ & BL21 & Glucose & $\begin{array}{l}P_{\text {trc }}-\text { YFP } \\
\text { pMB1 }\end{array}$ & $0.21 \pm 0.01$ \\
\hline$P_{\text {tac }} \mathrm{pMB1}^{\prime}$ & $\mathrm{BL} 21$ & Glycerol & $\begin{array}{l}P_{\text {tac }}-Y_{F P} \\
\text { pMB1 }^{\prime}\end{array}$ & $0.22 \pm 0.01$ \\
\hline $\begin{array}{l}\mathrm{P}_{\mathrm{BAD}} \\
\text { pMB1 }^{\prime}\end{array}$ & BL21 & Glycerol & $\begin{array}{l}\mathrm{P}_{\mathrm{BAD}}-\mathrm{YFP} \\
\mathrm{pMB1} 1^{\prime}\end{array}$ & $0.17 \pm 0.02$ \\
\hline $\mathrm{P}_{\text {T7lac }} \mathrm{P} 15 \mathrm{~A}$ & BL21 $\triangle a c k A$ & Glycerol & $\begin{array}{l}\text { P }_{\text {T7lac }} \text {-YFP } \\
\text { p15A }\end{array}$ & $0.24 \pm 0.03$ \\
\hline$P_{\text {trc }}$ P15A & BL21 & Glycerol & $P_{\text {trc }}-$ YFP p 15A & $0.5 \pm 0.05$ \\
\hline$P_{\text {tac }} \mathrm{p} 15 \mathrm{~A}$ & BL21 & Glucose & $P_{\text {tac }}-$ YFP p15A & $0.65 \pm 0.05$ \\
\hline PBAD P15A & BL21 $\Delta$ ackA & Glycerol & $\begin{array}{l}P_{B A D}-Y F P \\
\text { p15A }\end{array}$ & $0.28 \pm 0.04$ \\
\hline
\end{tabular}

Growth rates of cultures with the highest YFP expression observed for each promoter were also calculated. E. coli strain and carbon source of each culture are shown. 

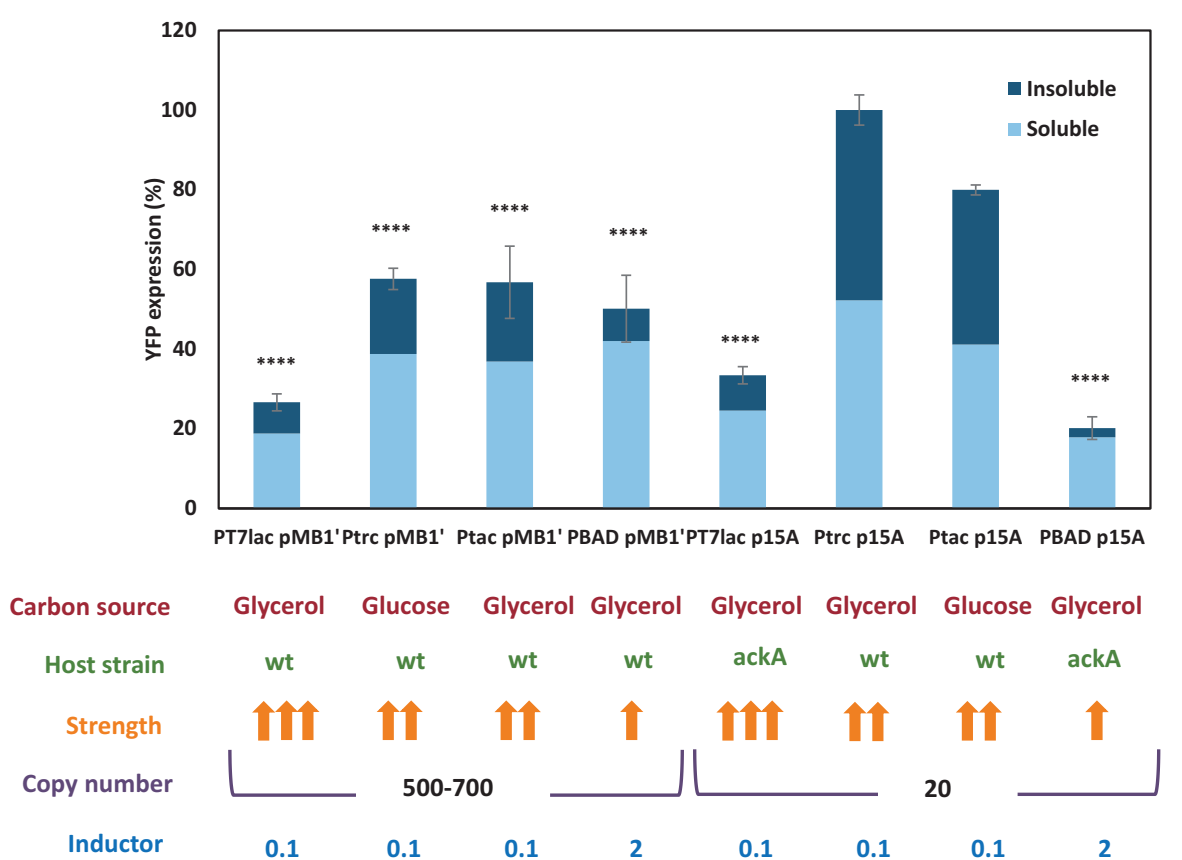

FIGURE 5 | Soluble and insoluble percentage of YFP measured for each expression vector. The fluorescence is indicated as a percentage, with $100 \%$ as observed with the pSF-p15A-trc-YFP vector. Carbon source, host strain, strength of the promoter, inductor concentration, and vector copies are shown under the graph. Statistical analysis by one way ANOVA was carried out with Graphpad Prism 7.0 [p value $<0.0001\left(^{(* * *)},<0.001\left(^{* * *}\right),<0.01\left(^{(*}\right)\right.$, and $\left.<0.05\left(^{*}\right)\right]$.

\section{Study of Recombinant Yellow Fluorescent Protein Protein Solubility}

One of the greatest drawbacks to obtain high recombinant protein yields with $E$. coli is the formation of inclusion bodies and protein precipitation, due to high expression, incorrect folding, aggregation, or low chaperone activity (Gopal and Kumar, 2013). Recombinant protein precipitation involves, in addition to a decrease in the yield of the production process, an alteration in the gene transcription of the strain (Baig et al., 2014). Hence, to optimize a large-scale recombinant protein production process, it is essential to know what proportion of the protein forms precipitates and what fraction remains in soluble form, and therefore functional for most subsequent applications. In order to know the percentage of soluble and insoluble YFP protein, batch cultures were carried out with E. coli growing under the conditions corresponding to the maximum expression observed for each vector (Figure 5). When cultures reached the stationary phase, soluble/insoluble fractions were analyzed by electrophoresis SDS-PAGE and subsequent densitometric analysis. Electrophoresis gels are shown in Supplementary Figure 2. Figure 5 results showed that insoluble YFP protein was present in all cultures. However, cultures where YFP was expressed under $\mathrm{P}_{\mathrm{BAD}}$ promoter control showed lower insoluble fraction. Moreover, cultures containing pSF-p15A-trc-YFP and pSF-p15A-tac-YFP vectors, of which YFP expression was the highest, showed a similar percentage of soluble and insoluble protein. This difference observed in the amount of protein precipitated according to the expression plasmid used is very relevant, since it is useless to achieve a high expression if most of the protein is precipitated together with the cell pellet. Therefore, this aspect should be studied previously when selecting an expression system, especially if we are faced with a protein with limited solubility.

\section{CONCLUSION}

Production of recombinant proteins has become an essential process to obtain drugs and other metabolites with high industrial interest. E. coli, as a prokaryotic model, is often the host of choice to produce proteins or other metabolites, especially when these proteins do not require complex post-translational modifications (Rosano and Ceccarelli, 2014). One of the advantages of E. coli as a host is the wide variety of expression vectors available. These expression vectors have different components, such as promoters or origins of replication, which are essential to tune the expression of our proteins of interest.

Metabolic burden associated to expression of heterologous proteins in microbial hosts is known to be one of the main drawbacks to achieve high recombinant protein yields. As has been demonstrated in this study, the negative effects of this imbalance can be minimized by tuning heterologous gene expression through vector copy number-promoter strength balance. Therefore, studies on plasmid copy number combined with the type of replication origin and promoter characteristics give important information to improve synthetic biology in heterologous protein and metabolite production method application (Koma et al., 2018; Shariati et al., 2021). In conclusion, the results show the importance of the transcription 
system optimization according to the characteristics of each process to achieve a successful result.

\section{DATA AVAILABILITY STATEMENT}

The original contributions presented in the study are included in the article/Supplementary Material, further inquiries can be directed to the corresponding author/s.

\section{AUTHOR CONTRIBUTIONS}

GLT, JG-J, and TDP conceptualized the study. JG-J prepared and wrote the original draft. JG-J, GLT, RSM, AMV, MCD, and TDP wrote, reviewed, and edited the manuscript. TDP performed the supervision and administration, and acquired the funding. All authors have read and agreed to the published version of the manuscript.

\section{REFERENCES}

Afroz, T., Biliouris, K., Kaznessis, Y., and Beisel, C. L. (2014). Bacterial sugar utilization gives rise to distinct single-cell behaviours. Mol. Microbiol. 93, 1093-1103. doi: 10.1111/mmi.12695

Aristidou, A. A., San, K. Y., and Bennett, G. N. (1999). Improvement of biomass yield and recombinant gene expression in Escherichia coli by using fructose as the primary carbon source. Biotechnol. Prog. 15, 140-145. doi: 10.1021/ bp980115v

Assenberg, R., Wan, P. T., Geisse, S., and Mayr, L. M. (2013). Advances in recombinant protein expression for use in pharmaceutical research. Curr. Opin. Struct. Biol. 23, 393-402. doi: 10.1016/j.sbi.2013.03.008

Badenhorst, C. P. S., and Bornscheuer, U. T. (2018). Getting momentum: from biocatalysis to advanced synthetic biology. Trends Biochem. Sci. 43, 180-198. doi: 10.1016/j.tibs.2018.01.003

Baig, F., Fernando, L. P., Salazar, M. A., Powell, R. R., Bruce, T. F., and Harcum, S. W. (2014). Dynamic transcriptional response of Escherichia coli to inclusion body formation. Biotechnol. Bioeng. 111, 980-999. doi: 10.1002/bit. 25169

Balzer, S., Kucharova, V., Megerle, J., Lale, R., Brautaset, T., and Valla, S. (2013). A comparative analysis of the properties of regulated promoter systems commonly used for recombinant gene expression in Escherichia coli. Microb. Cell Fact. 12, 1-14. doi: 10.1186/1475-2859-12-26

Bernal, V., Castaño-Cerezo, S., and Cánovas, M. (2016). Acetate metabolism regulation in Escherichia coli: carbon overflow, pathogenicity, and beyond. Appl. Microbiol. Biotechnol. 100, 8985-9001. doi: 10.1007/s00253-016-7832-x

Blount, Z. D. (2015). The unexhausted potential of E. coli. Elife 4, 1-12. doi: 10.7554/eLife.05826

Brautaset, T., Lale, R., and Valla, S. (2009). Positively regulated bacterial expression systems. Microb. Biotechnol. 2, 15-30. doi: 10.1111/j.1751-7915.2008.00048.x

Chandran Sathesh-Prabu, and Lee, S. K. (2018). "Genome Editing Tools for Escherichia coli and Their Application in Metabolic Engineering and Synthetic Biology," in Emerging Areas in Bioengineering, ed. C. HoNam (Germany: Wiley-VCH Verlag GmbH \& Co), 307-321.

Chew, F. N., and Tan, W. S. (2012). Statical optimization of green fluorescent protein production from Escherichia coli BL21(DE3). Prep. Biochem. Biotechnol. 42, 535-550.

Chiang, C. J., Hu, M. C., and Chao, Y. P. (2020). A strategy to improve production of recombinant proteins in Escherichia coli based on a Glucose-Glycerol Mixture and Glutamate. J. Agric. Food Chem. 68, 8883-8889. doi: 10.1021/acs. jafc.0c03671

Choi, Y. J., Morel, L., Le François, T., Bourque, D., Lucie, B., Groleau, D., et al. (2010). Novel, versatile, and tightly regulated expression system for Escherichia

\section{FUNDING}

This work was supported by the Ministry of Science, Innovation and Universities, The State Research Agency, and the European Regional Development Fund (RTI2018-094393B-C21-MCIU/AEI/FEDER, UE), and the Seneca FoundationScience and Technology Agency for the Region of Murcia (20786/PI/18). GLT is a recipient of a PhD fellowship from the Seneca Foundation (20715/FPI/18). RSM is a recipient of a FPU$\mathrm{PhD}$ fellowship from the Ministry of Science, Innovation and Universities (FPU18/00545).

\section{SUPPLEMENTARY MATERIAL}

The Supplementary Material for this article can be found online at: https://www.frontiersin.org/articles/10.3389/fmicb. 2021.682001/full\#supplementary-material

coli strains. Appl. Environ. Microbiol. 76, 5058-5066. doi: 10.1128/AEM.0041310

Cleto, S., Jensen, J. V. K., Wendisch, V. F., and Lu, T. K. (2016). Corynebacterium glutamicum metabolic engineering with CRISPR interference (CRISPRi). ACS Synth. Biol. 5, 375-385. doi: 10.1021/acssynbio.5b00216

Clomburg, J. M., and Gonzalez, R. (2013). Anaerobic fermentation of glycerol: a platform for renewable fuels and chemicals. Trends Biotechnol. 31, 20-28. doi: 10.1016/j.tibtech.2012.10.006

De Mey, M., Maertens, J., Lequeux, G. J., Soetaert, W. K., and Vandamme, E. J. (2007). Construction and model-based analysis of a promoter library for E. coli: An indispensable tool for metabolic engineering. BMC Biotechnol. 7:34. doi: 10.1186/1472-6750-7-34

Fragoso-Jiménez, J. C., Baert, J., Nguyen, T. M., Liu, W., Sassi, H., Goormaghtigh, F., et al. (2019). Growth-dependent recombinant product formation kinetics can be reproduced through engineering of glucose transport and is prone to phenotypic heterogeneity. Microb. Cell Fact. 18, 1-16. doi: 10.1186/s12934-0191073-5

Gallego Jara, J., De Diego, T., Real, A., Conesa, A. E., Manjón, A., and Cánovas, M. (2015). Lycopene overproduction and in situ extraction in organic - aqueous culture systems using a metabolically engineered Escherichia coli. AMB Express 5, 1-10. doi: 10.1186/s13568-015-0150-3

Gopal, G. J., and Kumar, A. (2013). Strategies for the production of recombinant protein in Escherichia coli. Protein J. 32, 419-425. doi: 10.1007/s10930-0139502-5

Gurramkonda, C., Gudi, S. K., and Koritala, B. S. (2018). Strategies for the production of soluble recombinant proteins using Escherichia coli: A review. J. Mol. Biol. Biotechnol. 3:6.

Guzman, L. M., Belin, D., Carson, M. J., and Beckwith, J. (1995). Tight regulation, modulation, and high-level expression by vectors containing the arabinose PBAD promoter. J. Bacteriol. 177, 4121-4130. doi: 10.1128/JB.177.14.41214130.1995

Hanahan, D. (1983). Studies on transformation of Escherichia coli with plasmids. J. Mol. Biol. 166, 557-580. doi: 10.1016/S0022-2836(83)80284-8

Huang, C.-J., Lin, H., and Yang, X. (2012). Industrial production of recombinant therapeutics in Escherichia coli and its recent advancements. J. Ind. Microbiol. Biotechnol. 39, 383-399. doi: 10.1007/s10295-011-1082-9

Jahn, M., Vorpahl, C., Hübschmann, T., Harms, H., and Müller, S. (2016). Copy number variability of expression plasmids determined by cell sorting and droplet digital PCR. Microb. Cell Fact. 15, 1-12. doi: 10.1186/s12934-0160610-8

Jervis, A. J., Carbonell, P., Taylor, S., Sung, R., Dunstan, M. S., Robinson, C. J., et al. (2019). SelProm: A queryable and predictive expression vector selection tool for Escherichia coli. ACS Synth. Biol. 8, 1478-1483. doi: 10.1021/acssynbio.8b00399 
Jones, K. L., Kim, S. W., and Keasling, J. D. (2000). Low-copy plasmids can perform as well as or better than high-copy plasmids for metabolic engineering of bacteria. Metab. Eng. 2, 328-338. doi: 10.1006/mben.2000.0161

Khlebnikov, A., and Keasling, J. D. (2002). Effect of lacY expression on homogeneity of induction from the Ptac and Ptrc promoters by natural and synthetic inducers. Biotechnol. Prog. 18, 672-674. doi: 10.1021/bp010141k

Kim, J. Y. H., and Cha, H. J. (2003). Down-regulation of acetate pathway through antisense strategy in Escherichia coli: Improved foreign protein production. Biotechnol. Bioeng. 83, 841-853. doi: 10.1002/bit.10735

Kim, T. S., Jung, H. M., Kim, S. Y., Zhang, L., Li, J., Sigdel, S., et al. (2015). Reduction of acetate and lactate contributed to enhancement of a recombinant protein production in E. coli BL21. J. Microbiol. Biotechnol. 25, 1093-1100. doi: $10.4014 / j m b .1503 .03023$

Koma, D., Kishida, T., Yamanaka, H., Moriyoshi, K., Nagamori, E., and Ohmoto, T. (2018). Escherichia coli chromosome-based T7-dependent constitutive overexpression system and its application to generating a phenylalanine producing strain. J. Biosci. Bioeng. 126, 586-595. doi: 10.1016/j.jbiosc.2018.05. 014

Kumar, J., Chauhan, A. S., Shah, R. L., Gupta, J. A., and Rathore, A. S. (2020). Amino acid supplementation for enhancing recombinant protein production in E. coli. Biotechnol. Bioeng. 117, 2420-2433. doi: 10.1002/bit.27371

Lee, S. K., and Keasling, J. D. (2005). A propionate-inducible expression system for enteric bacteria. Appl. Environ. Microbiol. 71, 6856-6862. doi: 10.1128/AEM.71. 11.6856-6862.2005

Li, Z., and Rinas, U. (2020). Recombinant protein production associated growth inhibition results mainly from transcription and not from translation. Microb. Cell Fact. 19, 1-11. doi: 10.1186/s12934-020-01343-y

Li, Z., and Rinas, U. (2021). Recombinant protein production-associated metabolic burden reflects anabolic constraints and reveals similarities to a carbon overfeeding response. Biotechnol. Bioeng. 118, 94-105. doi: 10.1002/bit.27553

Lin-Chao, S., Chen, W. T., and Wong, T. T. (1992). High copy number of the pUC plasmid results from a Rom/Rop-suppressible point mutation in RNA II. Mol. Microbiol. 6, 3385-3393. doi: 10.1111/j.1365-2958.1992.tb02206.x

Lozano Terol, G., Gallego-Jara, J., Sola Martínez, R. A., Cánovas Díaz, M., and De Diego Puente, T. (2019). Engineering protein production by rationally choosing a carbon and nitrogen source using E. coli BL21 acetate metabolism knockout strains. Microb. Cell Fact. 18, 1-19. doi: 10.1186/s12934-019-1202-1

Mairhofer, J., Scharl, T., Marisch, K., Cserjan-Puschmann, M., and Striedner, G. (2013). Comparative transcription profiling and in-depth characterization of plasmid-based and plasmid-free Escherichia coli expression systems under production conditions. Appl. Environ. Microbiol. 79, 3802-3812. doi: 10.1128/ AEM.00365- 13

Marschall, L., Sagmeister, P., and Herwig, C. (2017). Tunable recombinant protein expression in E. coli: promoter systems and genetic constraints. Appl. Microbiol. Biotechnol. 101, 501-512. doi: 10.1007/s00253-016-8045-z

McCarty, N. S., and Ledesma-Amaro, R. (2019). Synthetic biology tools to engineer microbial communities for biotechnology. Trends Biotechnol. 37, 181-197. doi: 10.1016/j.tibtech.2018.11.002

Mertens, N., Remaut, E., and Fiers, W. (1995). Versatile, multi-featured plasmids for high-level expression of heterologous genes in Escherichia coli: overproduction of human and murine cytokines. Gene 164, 9-15. doi: 10.1016/ 0378-1119(95)00505-Z

Mühlmann, M. J., Forsten, E., Noack, S., and Büchs, J. (2018). Prediction of recombinant protein production by Escherichia coli derived online from indicators of metabolic burden. Biotechnol. Prog. 34, 1543-1552. doi: 10.1002/ btpr. 2704

Müller-Hill, B., Crapo, L., and Gilbert, W. (1968). Mutants that mke more lac repressor. Proc. Natl. Acad. Sci. U. S. A. 59, 1259-1264. doi: 10.1073/pnas.59. 4.1259

Ning, Y., Wu, X., Zhang, C., Xu, Q., Chen, N., and Xie, X. (2016). Pathway construction and metabolic engineering for fermentative production of ectoine in Escherichia coli. Metab. Eng. 36, 10-18. doi: 10.1016/j.ymben.2016. 02.013

Niu, D., Tian, K., Prior, B. A., Wang, M., Wang, Z., Lu, F., et al. (2014). Highly efficient L-lactate production using engineered Escherichia coli with dissimilar temperature optima for L-lactate formation and cell growth. Microb. Cell Fact. 13, 1-11. doi: 10.1186/1475-2859-13-78
Penumetcha, P., Lau, K., Zhu, X., Davis, K., Eckdahl, T. T., and Campbell, A. M. (2010). Improving the lac system for synthetic biology. Bios 81, 7-15.

Phue, J. N., Sang, J. L., Trinh, L., and Shiloach, J. (2008). Modified Escherichia coli B (BL21), a superior producer of plasmid DNA compared with Escherichia coli K (DH5 $\alpha$ ). Biotechnol. Bioeng. 101, 831-836. doi: 10.1002/bit.21973

Rosano, G. L., and Ceccarelli, E. A. (2014). Recombinant protein expression in Escherichia coli: Advances and challenges. Front. Microbiol. 5:172. doi: 10.3389/ fmicb.2014.00172

Rosano, G. L., Morales, E. S., and Ceccarelli, E. A. (2019). New tools for recombinant protein production in Escherichia coli: A 5-year update. Protein Sci. 28, 1412-1422. doi: 10.1002/pro.3668

Rueden, C. T., Schindelin, J., Hiner, M. C., DeZonia, B. E., Walter, A. E., Arena, E. T., et al. (2017). ImageJ2: ImageJ for the next generation of scientific image data. BMC Bioinform. 18:529. doi: 10.1186/s12859-017-1934-z

Sanchez-Garcia, L., Martín, L., Mangues, R., Ferrer-Miralles, N., Vázquez, E., and Villaverde, A. (2016). Recombinant pharmaceuticals from microbial cells: A 2015 update. Microb. Cell Fact. 15, 1-7. doi: 10.1186/s12934-016-0437-3

Schleif, R. (2010). AraC protein, regulation of the L-arabinose operon in Escherichia coli, and the light switch mechanism of AraC action. FEMS Microbiol. Rev. 34, 779-796. doi: 10.1111/j.1574-6976.2010.00226.x

Selzer, G., Som, T., Itoh, T., and Tomizawa, J. (1983). The origin of replication of plasmid p15A and comparative studies on the nucleotide sequences around the origin of related plasmids. Cell 32, 119-129. doi: 10.1016/0092-8674(83)90 502-0

Shariati, F. S., Keramati, M., Valizadeh, V., Cohan, R. A., and Norouzian, D. (2021). Comparison of E. coli based self-inducible expression systems containing different human heat shock proteins. Sci. Rep. 11, 1-10. doi: 10.1038/s41598021-84188-8

Silva, F., Queiroz, J. A., and Domingues, F. C. (2012). Evaluating metabolic stress and plasmid stability in plasmid DNA production by Escherichia coli. Biotechnol. Adv. 30, 691-708. doi: 10.1016/j.biotechadv.2011.12.005

Silverstone, A. E., Arditti, R. R., and Magasanik, B. (1970). Catabolite-insensitive revertants of lac promoter mutants. Proc. Natl. Acad. Sci. U. S. A. 66, 773-779. doi: 10.1073/pnas.66.3.773

Slouka, C., Kopp, J., Strohmer, D., Kager, J., Spadiut, O., and Herwig, C. (2019). Monitoring and control strategies for inclusion body production in E. coli based on glycerol consumption. J. Biotechnol. 296, 75-82. doi: 10.1016/j.jbiotec.2019. 03.014

Smolke, C. D., and Keasling, J. D. (2002). Effect of copy number and mRNA processing and stabilization on transcript and protein levels from an engineered dual-gene operon. Biotechnol. Bioeng. 78, 412-424. doi: 10.1002/bit.10218

Tan, J., Sastry, A. V., Fremming, K. S., Bjørn, S. P., Hoffmeyer, A., Seo, S., et al. (2020). Independent component analysis of E. coli's transcriptome reveals the cellular processes that respond to heterologous gene expression. Metab. Eng. 61, 360-368. doi: 10.1016/j.ymben.2020.07.002

Terpe, K. (2006). Overview of bacterial expression systems for heterologous protein production: From molecular and biochemical fundamentals to commercial systems. Appl. Microbiol. Biotechnol. 72, 211-222. doi: 10.1007/s00253-0060465-8

Vargas-Maya, N., and Franco, B. (2017). "Escherichia coli as a model organism and its application in biotechnology," in Escherichia coli-Recent Aavances on pysiology, pathogenesis and biotechnological applications, ed. S. Amidou (London: IntchOpen), 253-274.

Vethanayagan, J. G. G., and Flower, A. M. (2005). Decreased gene expression from T7 promoters may due to impaired production of active T7 RNA polymerase. Microb. Cell Fact. 4, 1-7. doi: 10.1186/1475-2859-4-3

Wang, R., Zhao, S., Wang, Z., and Koffas, M. A. (2020). Recent advances in modular co-culture engineering for synthesis of natural products. Curr. Opin. Biotechnol. 62, 65-71. doi: 10.1016/j.copbio.2019.09.004

Wang, Z., Jin, L., Yuan, Z., Wegrzyn, G., and Wegrzyn, A. (2009). Classification of plasmid vectors using replication origin, selection marker and promoter as criteria. Plasmid 61, 47-51. doi: 10.1016/j.plasmid.2008.09.003

William Studier, F., Rosenberg, A. H., Dunn, J. J., and Dubendorff, J. W. (1990). Use of T7 RNA polymerase to direct expression of cloned genes. Methods Enzymol. 185, 60-89. doi: 10.1016/0076-6879(90)85008-C

Wu, G., Yan, Q., Jones, J. A., Tang, Y. J., Fong, S. S., and Koffas, M. A. G. (2016). Metabolic burden: cornerstones in synthetic biology and metabolic engineering 
applications. Trends Biotechnol. 34, 652-664. doi: 10.1016/j.tibtech.2016. 02.010

Wu, H., Pei, J., Jiang, Y., Song, X., and Shao, W. (2010). pHsh vectors, a novel expression system of Escherichia coli for the large-scale production of recombinant enzymes. Biotechnol. Lett. 32, 795-801. doi: 10.1007/s10529-0100223-y

Wu, J., Cheng, S., Cao, J., Qiao, J., and Zhao, G. (2019). Systematic optimization of limonene production in engineered Escherichia coli. J. Agric. Food Chem. 67, 7087-7097. doi: 10.1021/acs.jafc.9b01427

Xu, W., Klumbys, E., Ang, E. L., and Zhao, H. (2020). Emerging molecular biology tools and strategies for engineering natural product biosynthesis. Metab. Eng. Commun. 10:e00108. doi: 10.1016/j.mec.2019.e00108

Yang, J., Joelle Ruff, A., Hamer, S. N., Cheng, F., and Schwaneberg, U. (2016). Screening through the PLICable promoter toolbox enhances protein production in Escherichia coli. Biotechnol. J. 11, 1639-1647. doi: 10.1002/biot. 201600270.Submitted
Zaslaver, A., Bren, A., Ronen, M., Itzkovitz, S., Kikoin, I., Shavit, S., et al. (2006). A comprehensive library of fluorescent transcriptional reporters for Escherichia coli. Nat. Methods 3, 623-628. doi: 10.1038/nmeth 895

Conflict of Interest: The authors declare that the research was conducted in the absence of any commercial or financial relationships that could be construed as a potential conflict of interest.

Copyright (C) 2021 Lozano Terol, Gallego-Jara, Sola Martínez, Martínez Vivancos, Cánovas Díaz and de Diego Puente. This is an open-access article distributed under the terms of the Creative Commons Attribution License (CC BY). The use, distribution or reproduction in other forums is permitted, provided the original author(s) and the copyright owner(s) are credited and that the original publication in this journal is cited, in accordance with accepted academic practice. No use, distribution or reproduction is permitted which does not comply with these terms. 